\title{
Flavobacterium odoratum: a species resistant to a wide range of antimicrobial agents
}

\author{
B. HOLMES, J. J. S. SNELL, AND S. P. LAPAGE
}

From the National Collection of Type Cultures, Central Public Health Laboratory, Colindale, London NW9 5HT, and the Microbiology Quality Control Laboratory, Neasden Hospital, Brentfield Road, London NW10 8EY, UK

SUMMARY During the period 1966-77, 24 strains of Flavobacterium odoratum were identified from among strains of Gram-negative, non-fermentative bacteria submitted to the National Collection of Type Cultures for computer-assisted identification. The $F$. odoratum strains showed resistance to therapeutic levels of gentamicin, tobramycin, amikacin, and carbenicillin as well as to several other antimicrobial agents generally useful in the treatment of infections caused by Gram-negative, nonfermentative bacteria. Two strains isolated from amputation stumps and another three strains isolated in significant numbers from urine specimens were possibly opportunist pathogens. The biochemical characteristics of the 24 strains, the proposed neotype strain of $F$. odoratum, and three strains representative of a group, referred to at the Center for Disease Control, Atlanta as group M-4f, were compared with those of biochemically similar species which may be isolated from clinical material.

The earliest recorded isolations of the species now known as Flavobacterium odoratum were made from the human intestine by Stutzer (1923) and Stutzer and Kwaschnina (1929). Although the strains could not be isolated from normal faeces but only from the faeces of patients suffering from typhoid fever, acute gastroenteritis, and relapsing fever, there was no suggestion that the strains were playing a pathogenic role, and animal pathogenicity tests proved negative. Holmes et al. (1977) proposed a neotype strain for $F$. odoratum (NCTC 11036) and provided a revised description of the species based upon an examination of the neotype and nine field strains which had been isolated from clinical material; they could find no reports of clinical isolations of the species since it was first described. The source of the isolates and the results of biochemical and antimicrobial susceptibility tests obtained by Holmes et al. (1977) are, for convenience, repeated in the present paper.

The recent isolation of a further 15 strains of $F$. odoratum, 10 in the UK, suggests that the organism may be widely distributed. The present account reports the results of biochemical tests and antimicrobial susceptibility tests of 28 strains of $F$. odoratum in order that the species may be more easily recognised in the clinical laboratory.

Received for publication 21 June 1978

\section{Material and methods}

STRAINS

Twenty-eight strains of $F$. odoratum were examined. They comprised 24 field strains referred to the National Collection of Type Cultures for computerassisted identification, the neotype strain maintained in the National Collection of Type Cultures (NCTC), Colindale (NCTC 11036), and three strains of group M-4f (Tatum et al., 1974), which were found to be identical with $F$. odoratum by Holmes et al. (1977). Clinical details of the field strains are summarised in Table 1; fuller details on strains 1 to 9 are given by Holmes et al. (1977).

BACTERIOLOGICAL STUDIES

The majority of tests used (Table 2) were incubated at $37^{\circ} \mathrm{C}$, and the methods employed were those used by Holmes et al. (1975). Susceptibility to antimicrobial agents was tested as described by Holmes et al. (1977).

\section{Results}

The 28 strains were Gram-negative rods and, with the exception of strain 21 , all produced, on nutrient agar, bright yellow colonies, which gave off a pleasant, strong, fruity, characteristic odour. After incubation 
Table 1 Strains of F. odoratum examined

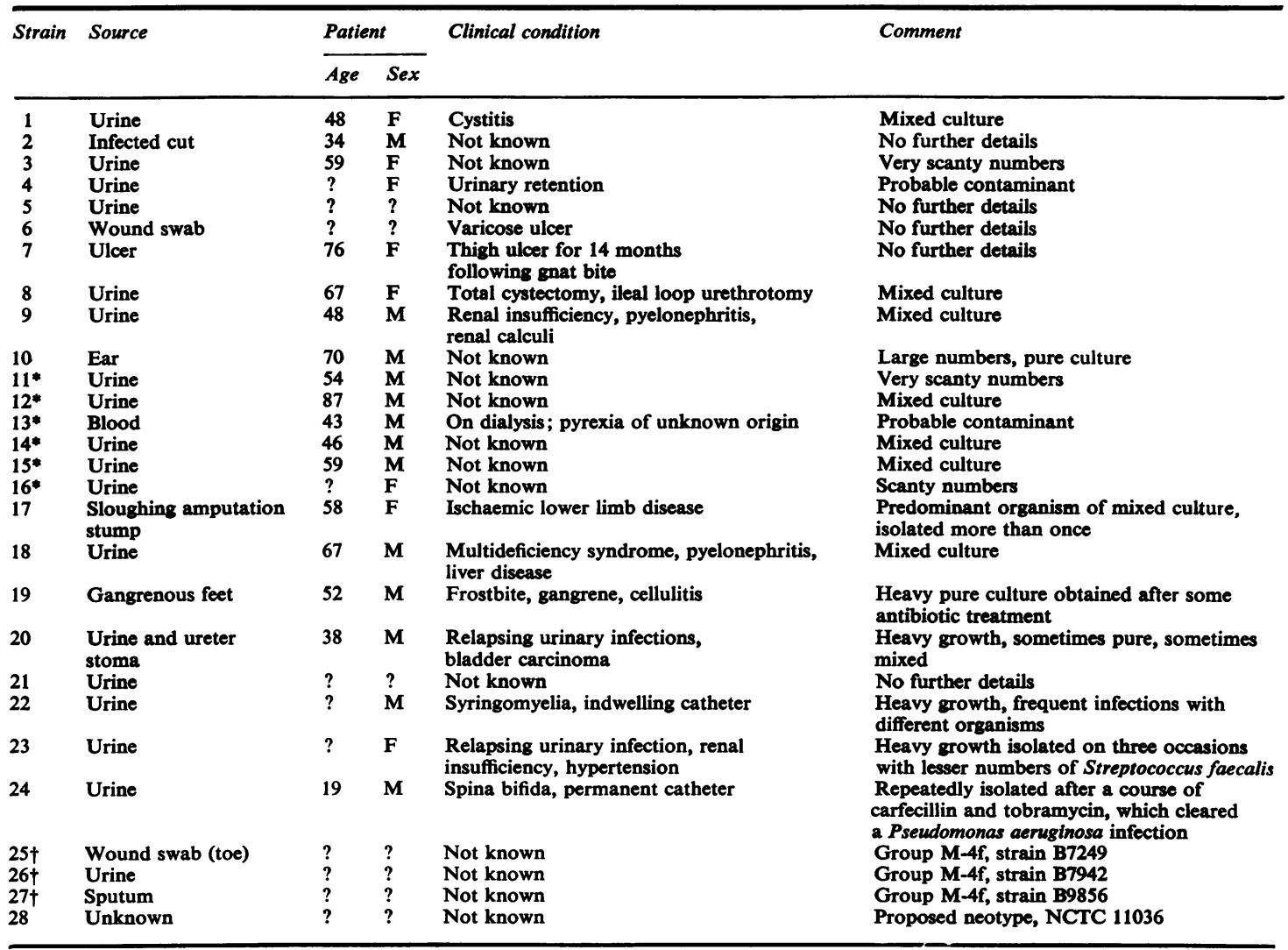

*Strains 11-16 were isolated in the same hospital over a period of more than two years, at intervals of at least two months. †Strains 25-27 are isolates of group M-4f (Tatum et al., 1974) sent to us by R. E. Weaver, Atlanta, Georgia, USA.

for 24 hours on nutrient agar four colonial types were observed among the strains. Strains 4, 5, 6, 7, 8, 15, 21 , and 22 produced effuse, spreading colonies of 3 to $4 \mathrm{~mm}$ in diameter with raised, shiny centres and dull, matt, spreading edges. On further incubation the whole colony became smooth and shiny (colonial type 1 of Holmes et al. (1977)). Colonies of strains 1, $3,11,12,13,18$, and 28 (NCTC 11036) showed the same appearance after 24 hours as those of type 1 , but they were smaller, about 1.0 to $1.5 \mathrm{~mm}$ in diameter (colonial type 2 of Holmes et al. (1977)). Colonies of strains $2,9,10,14,16,17,19,23,24,25$, 26 , and 27 were smooth, shiny, and convex with no spreading edge and with a diameter of 0.5 to $1.0 \mathrm{~mm}$ after 24 hours; however, after further incubation, the colonies took the same appearance as those of type 1 (colonial type 3 of Holmes et al. (1977)).The colonies of strain 20 were mucoid and thus constituted a fourth colonial type not observed by Holmes et al. (1977) in their series.

The biochemical test results for the strains are given in Table 2 and are arranged by the tests in which all strains gave a positive or negative result and tests in which the strains differed. The strains were very homogeneous with respect to their biochemical characteristics, showing differences between the strains in only eight of the 65 tests carried out. Despite giving negative results for most of the biochemical characters tested (Table 2), the strains had several distinguishing characteristics by which they may be recognised. All but one of the isolates produced a bright yellow pigment on nutrient agar and gave off a characteristic fruity odour. All of the isolates were non-motile and nonsaccharolytic, and produced an alkaline reaction in glucose Hugh and Leifson O-F medium. All of the isolates also digested casein and produced both extracellular deoxyribonuclease and gelatinase. Urease was produced, and a particular characteristic of the strains was their ability to reduce nitrite but not nitrate.

Results of susceptibility tests to antimicrobial 
Table 2 Biochemical characters of F. odoratum

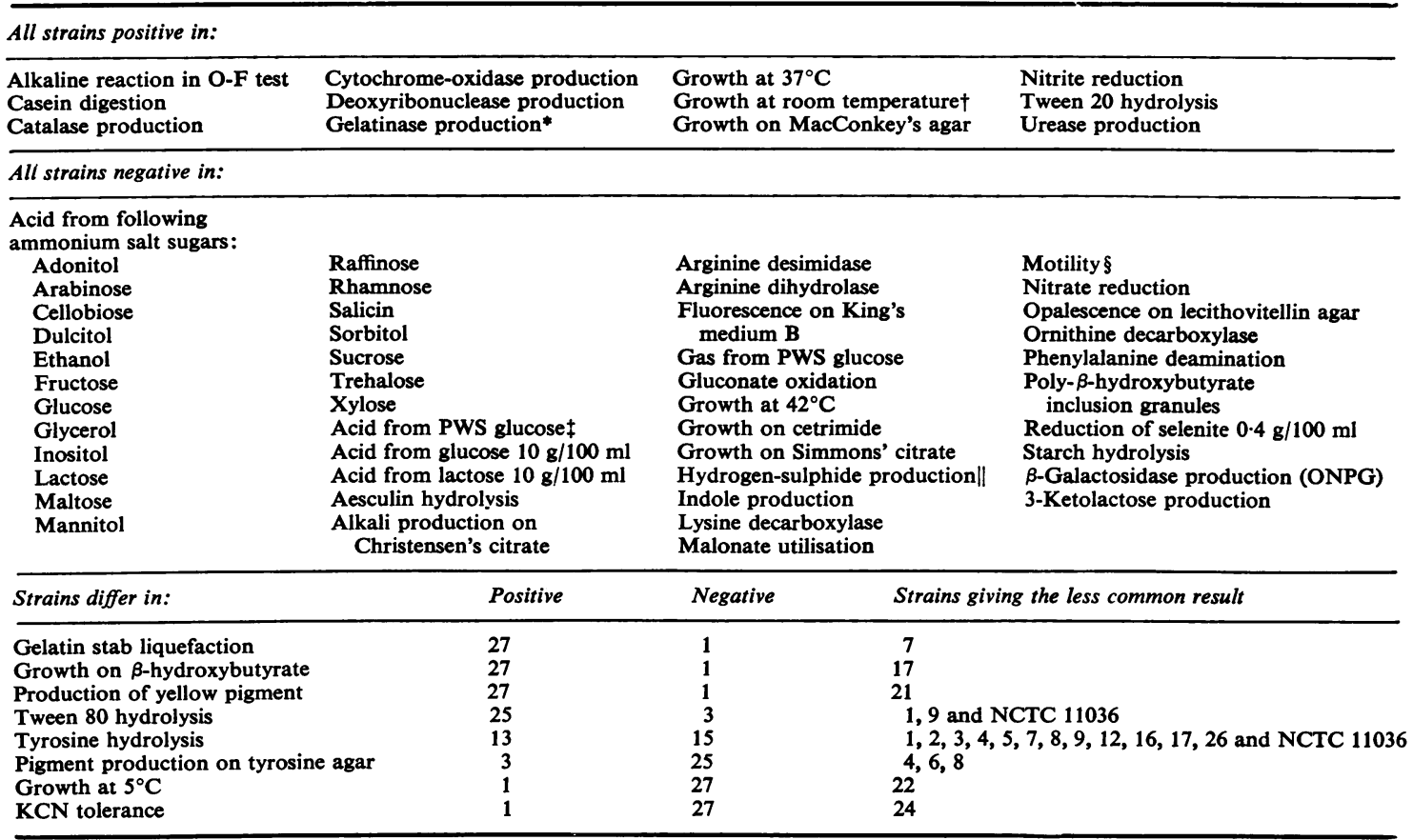

* By plate method.

$\dagger 18-22^{\circ} \mathrm{C}$.

$\ddagger$ PWS $=$ peptone water sugar.

$\|$ By both lead acetate paper and triple sugar iron agar methods.

\$At both $37^{\circ} \mathrm{C}$ and room temperature.

agents are given in Table 3 . The strains were fully resistant to clinically obtainable levels of streptomycin, kanamycin, gentamicin, tobramycin, amikacin, ampicillin, carbenicillin, chloramphenicol, tetracycline, polymyxin $\mathrm{B}$, and erythromycin; and resistant or moderately sensitive to sulphamethoxazole, co-trimoxazole, cephaloridine, and nalidixic acid.

\section{Discussion}

Three organisms occasionally isolated from clinical material may be confused with $F$. odoratum: Alcaligenes odorans, Flavobacterium breve, and the group IIf of Tatum et al. (1974). Like $F$. odoratum both $A$. odorans and group IIf produce an alkaline reaction in glucose Hugh and Leifson O-F medium and are nonsaccharolytic in our ammonium salt sugar medium (except for acid production from ethanol by $A$. odorans). Strains of $A$. odorans also produce a fruity odour and reduce nitrite but not nitrate. Strains of group IIf, which show affinities to both the genus Flavobacterium and the genus Moraxella (Owen and Snell, 1973), differ from $F$. odoratum in
Table 3 Susceptibility of F. odoratum to antimicrobial agents*

\begin{tabular}{|c|c|c|c|c|c|c|c|c|c|c|}
\hline \multirow{2}{*}{$\begin{array}{l}\text { Antimicrobial } \\
\text { agent }\end{array}$} & \multicolumn{10}{|c|}{$M I C(\mu g / m l)$} \\
\hline & $<1$ & 1 & 2 & 4 & 8 & 16 & 32 & 64 & 128 & $>128$ \\
\hline $\begin{array}{l}\text { Sulphamethoxazole } \\
\text { Co-trimoxazole } \\
\text { Streptomycin } \\
\text { Kanamycin } \\
\text { Gentamicin } \\
\text { Tobramycin } \\
\text { Amikacin } \\
\text { Ampicillin } \\
\text { Carbenicillin } \\
\text { Cephaloridine } \\
\text { Erythromycin } \\
\text { Chloramphenicol } \\
\text { Tetracycline } \\
\text { Polymyxin B } \\
\text { Nalidixic acid }\end{array}$ & 2 & $\begin{array}{l}1 \\
9\end{array}$ & $\begin{array}{r}1 \\
10\end{array}$ & $\begin{array}{l}4 \\
2 \\
2 \\
1 \\
8\end{array}$ & $\begin{array}{l}2 \\
1\end{array}$ & $\begin{array}{r}6 \\
9 \\
8 \\
1 \\
12\end{array}$ & $\begin{array}{r}7 \\
2 \\
3 \\
10 \\
3 \\
1\end{array}$ & $\begin{array}{r}4 \\
1 \\
1 \\
1 \\
1 \\
3 \\
2 \\
2 \\
14 \\
1\end{array}$ & $\begin{array}{r}4 \\
10 \\
2 \\
1 \\
\\
1 \\
5 \\
12 \\
1 \\
1 \\
7\end{array}$ & $\begin{array}{r}15 \\
2 \\
23 \\
26 \\
24 \\
17 \\
15 \\
4 \\
10\end{array}$ \\
\hline
\end{tabular}

* 26 strains tested except for tobramycin and amikacin, for which 17 strains were tested.

producing indole (however, a sensitive method, extraction with xylene followed by the addition of Ehrlich's reagent, is necessary to demonstrate the 
indole production). Holmes et al. (1978) have proposed a neotype strain for $F$. breve (NCTC 11099) and have provided a revised description of the species based upon an examination of six clinical isolates (two from urine specimens) and a strain maintained in a culture collection (ATCC 14234). Like $F$. odoratum, $F$. breve is yellow-pigmented and is also resistant to therapeutic levels of antimicrobial agents such as gentamicin and carbenicillin, which are generally useful in the treatment of infections caused by Gram-negative, non-fermentative bacteria. However, when incubated at $30^{\circ} \mathrm{C}$, unlike $F$. odoratum, strains of $F$. breve generally produce acid from glucose and maltose in ammonium salt sugar medium. Strains of $F$. breve further differ from $F$. odoratum in failing to reduce nitrite or to produce urease and in producing indole (using Ehrlich's reagent). Characters by which $F$. odoratum may be distinguished from $A$. odorans, $F$. breve, and group IIf are given in Table 4.

While there is no definite evidence that any of our strains were acting as pathogens it is possible that five were doing so. Strain 17 , although isolated in mixed culture from an amputation stump, was the predominant organism and was isolated on more than one occasion. Strain 19 was the only organism isolated, and as a heavy growth, from gangrenous feet. Strains 20, 22, and 23, like many of our isolates, came from urine specimens, but all three of these strains were isolated in significant numbers (> 100000 bacterial cells/ml). Stutzer (1923) considered that his strains of Bacterium faecale aromaticum (as $F$. odoratum was then called) played only a saprophytic role in the human intestine because he could not demonstrate pathogenicity of his strains in experimental animals. Intradermal, intraperitoneal, and intravenous injections of cultures of $\boldsymbol{B}$. faecale aromaticum into mice, guinea-pigs, and rabbits produced no demonstrable response (Stutzer, 1923). Stutzer and Kwaschnina (1929) could not recover $F$. odoratum from normal faeces, and they isolated strains of this species only from the faeces of patients with typhoid fever, acute gastroenteritis, and relapsing fever. They did not suggest that it followed that $F$. odoratum was playing a pathogenic role in these patients but they did consider that isolation of this species was an indication of pathological processes in the intestine. It is possible, from the clinical circumstances in which our strains were isolated, that $F$. odoratum may be a low-grade opportunist pathogen. The resistance of $F$. odoratum to a wide range of antimicrobial agents (including gentamicin, tobramycin, amikacin, and carbenicillin) to which Gram-negative, non-fermentative bacteria might be expected to be susceptible suggests that any infections due to this species would prove difficult to treat, especially in the case of systemic infections. Drasar et al. (1976) reported minimum inhibitory concentrations (MICs) for seven Flavobacterium strains they examined. They did not, unfortunately, identify their strains to species level nor report their biochemical characteristics but,

Table 4 Characteristics for differentiation of $\mathrm{F}$. odoratum and phenetically similar bacteria*

\begin{tabular}{|c|c|c|c|c|}
\hline Test & $\begin{array}{l}\text { Flavobacterium } \\
\text { odoratum }\end{array}$ & $\begin{array}{l}\text { Alcaligenes } \\
\text { odorans }\end{array}$ & $\begin{array}{l}\text { Flavobacterium } \\
\text { breve }\end{array}$ & $\begin{array}{l}\text { Group } \\
\text { IIf }\end{array}$ \\
\hline Acid from ASS $\dagger$ glucose & - & - & $6 / 7 \ddagger$ & - \\
\hline Acid from ASS ethanol & - & + & - & - \\
\hline Acid from ASS maltose & - & - & $6 / 7$ & - \\
\hline Alkali production on Christensen's citrate & - & + & - & - \\
\hline Alkali production in glucose Hugh and Leifson O-F medium & + & + & $-\|$ & + \\
\hline Casein digestion & + & - & + & + \\
\hline Deoxyribonuclease production & + & - & $6 / 7$ & $11 / 16$ \\
\hline Gelatinase production & + & - & + & + \\
\hline Growth at $42^{\circ} \mathrm{C}$ & - & + & - & + \\
\hline Growth on cetrimide & - & + & - & - \\
\hline Growth on Simmons' citrate & - & $+\dot{T}$ & - & - \\
\hline Motility & - & + & - & - \\
\hline Nitrite reduction & + & + & - & - \\
\hline Production of yellow pigment & $27 / 28$ & - & + & - \\
\hline Tween 20 hydrolysis & + & - & + & + \\
\hline Tween 80 hydrolysis & $25 / 28$ & - & $3 / 7$ & $6 / 16$ \\
\hline Tyrosine hydrolysis & $13 / 28$ & + & - & - \\
\hline Urease production & + & - & - & - \\
\hline
\end{tabular}

*Symbols: + , all strains tested positive; - , all strains tested negative.

The phenotypic results for $F$. odoratum were derived from this study, those for $F$. breve were derived from Holmes et al. (1978), while those for A. odorans and group IIf are from NCTC unpublished data.

†ASS, ammonium salt sugar medium. $F$. breve produces acid only at $30^{\circ} \mathrm{C}$ and may require incubation for more than five days before a positive result is obtained.

$\ddagger$ Number of strains showing characters/number of strains tested.

$\|$ Of seven strains examined, three gave an oxidative reaction, and in four no change in the medium was observed. 
like our strains, their seven had MICs for gentamicin of $\geqslant 128 \mu \mathrm{g} / \mathrm{ml}$, for tobramycin of $>256 \mu \mathrm{g} / \mathrm{ml}$, and for amikacin of $\geqslant 64 \mu \mathrm{g} / \mathrm{ml}$. They further stated that the problem of treating infections caused by gentamicin-resistant Flavobacterium spp ... remains unsolved'.

We are grateful to all those who sent us strains of $F$. odoratum for identification, especially those who also kindly provided additional clinical details relating to the isolation of their strains. In particular, we thank the following: G. Fenwick for sending us the series of strains 11 to 16 ; A. A. B. Mitchell for supplying extensive clinical information relating to the isolation of strain $19 ;$ R. E. Weaver for supplying us with a culture of strain 22 and three strains of group M-4f, and for putting us in contact with J. Vandepitte; and J. Vandepitte for supplying us with cultures of strains 20,21 , and 23 and for passing on our requests for further clinical details to those who originally isolated strains $20,21,22$, and 23.

\section{References}

Drasar, F. A., Farrell, W., Maskell, J., and Williams, J. D. (1976). Tobramycin, amikacin, sissomicin, and gentamicin resistant Gram-negative rods. British Medical Journal, 2, 1284-1287.

Holmes, B., Lapage, S. P., and Malnick, H. (1975). Strains of Pseudomonas putrefaciens from clinical material. Journal of Clinical Pathology, 28, 149-155.
Holmes, B., Snell, J. J. S., and Lapage, S. P. (1977). Revised description, from clinical isolates, of Flavobacterium odoratum Stutzer and Kwaschnina 1929, and designation of the neotype strain. International Journal of Systematic Bacteriology, 27, 330-336.

Holmes, B., Snell, J. J. S., and Lapage, S. P. (1978). Revised description, from clinical strains, of Flavobacterium breve (Lustig) Bergey et al. 1923, and proposal of the neotype strain. International Journal of Systematic Bacteriology, 28, 201-208.

Owen, R. J., and Snell, J. J. S. (1973). Comparison of group IIf with Flavobacterium and Moraxella. Antonie van Leeuwenhoek Journal of Microbiology and Serology, 39, 473-480.

Stutzer, M. J. (1923). Zur Frage über die Fäulnisbakterien im Darm. Zentralblatt für Bakteriologie, Parasitenkunde und Infektionskrankheiten, I Abt. Originale, 91, 87-90.

Stutzer, M., and Kwaschnina, A. (1929). In Aussaaten aus den Fäzes des Menschen gelbe Kolonien bildende Bakterien (Gattung Flavobacterium u.a.). Zentralblatt für Bakteriologie, Parasitenkunde und Infektionskrankheiten, I Abt. Originale, 113, 219-225.

Tatum, H. W., Ewing, W. H., and Weaver, R. E. (1974). Miscellaneous Gram-negative bacteria. In Manual of Clinical Microbiology, 2nd edition, edited by E. H. Lennette, E. H. Spaulding, and J. P. Truant, pp. 270294. American Society for Microbiology, Washington, DC.

Requests for reprints to: B. Holmes, National Collection of Type Cultures, Central Public Health Laboratory, Colindale Avenue, London NW9 5HT, UK. 